\title{
Relationship between Transformational Leadership and Innovation
}

\author{
Mohammad Hasan akbari \\ Master of Public \\ Administration (Governmental \\ Management) \\ Farabi Campus, University of \\ Tehran \\ Birjand, Iran
}

\author{
Gholamreza Younesi \\ Master of Geography, Rural \\ Planning \\ Payam-e-Noor university of \\ Birjand \\ Birjand, Iran
}

\author{
Mahmood Zohoori \\ Master of Environmental \\ Management \\ Putra University of Malaysia \\ Birjand, Iran
}

\begin{abstract}
This research attempts to examine the relationship between transformational leadership's components (vision, inspirational communication, intellectual stimulation, personal recognition, and supportive leadership) and innovation (configuration, offering, and experience). The scope of study is the government organization of the Iran. The result of multiple regression analysis shows that most of components of transformational leadership have significant impact on innovation.
\end{abstract}

Keywords: Innovation, Transformational leadership, Government organization, Iran

\section{INTRODUCTION}

The role of innovation to improve economic growth is one of the important topics which has been discussed in various researches. Different definitions have been suggested for innovation which are at some point consistent among experts: innovation is considered as a process of translation regarding an idea or invention toward a product or service that creates value that customers will to pay for it. Moreover, the suggested categories for innovation always have been the topic of various investigations. Different classifications are critical due to they result in recognizing the important factors. It appears that 10 suggested categories by Keeley et al (2013) have studies innovation more particularly which contributes to better understanding of innovation enablers and also existed methods in management science.
Transformational leadership is one of the main tools in the human resource management. Previous research have shown that transformational leadership can affect innovation and organization performance. Followed by extant research, current research attempts to find how different components of transformational leadership affect various innovation's components.

The scope of this study is government organizations of Iran located in 4 largest cities of Iran. Focusing on this type or organization is very important because of the importance of Iranian organizations which are linked to the government. In other words, any improvement in innovation can affect economic growth of country significantly. Besides, the customer of this type of organizations could be very citizen of Iran. 


\section{LITERATURE REVIEW}

\subsection{Innovation}

Among many different categorizations of different kinds of innovation, the OECD (2005) in Oslo Manual is one of the most recent accepted classifications that introduces four main types of innovation including process innovation, product innovation, marketing innovation and also organizational innovation (OI). Technological innovation covers process and product innovations. On the other hand, non-technological innovation includes organizational and marketing innovations. According to Schumpeter (1934) and other famous innovation scholars for example Damanpour (1991) and Edquist, Hommen and McKelvey (2001) different types of innovation have been classified in many ways. The Resource Based View (RBV) employs internal characteristics of organizations to discuss their heterogeneity in performance and strategy. Based on main focus of RBV, only those organizations with specific resources and abilities and certain characteristics can reach competitive advantage and so will gain improved performance. The degree of distinctiveness of factors depend on their durability, values, rarity and non-substitutability, appropriateness and inimitability of created rents (Zohoori et al., 2013; Barney, 1991).

Moreover, Keeley et al (2013) have categorized innovation according to three components which are experience, offering and configuration (See Table 1).

Table1: Different categories of innovation according to Keeley et al. (20013)

\begin{tabular}{|c|c|c|c|c|c|c|c|c|c|}
\hline \multicolumn{4}{|c|}{ Configuration } & \multicolumn{2}{|l|}{ Offering } & \multicolumn{4}{|l|}{ Expenience } \\
\hline $\begin{array}{l}\text { Profit } \\
\text { Model }\end{array}$ & Network & Structure & Process & $\begin{array}{l}\text { Product } \\
\text { Performance }\end{array}$ & $\begin{array}{l}\text { Product } \\
\text { System }\end{array}$ & Service & Channel & Brand & $\begin{array}{l}\text { Customer } \\
\text { Engagement }\end{array}$ \\
\hline $\begin{array}{l}\text { How } \\
\text { Compan } \\
\text { y Makes } \\
\text { Money? }\end{array}$ & $\begin{array}{l}\text { How } \\
\text { Compan } \\
y \\
\text { comnects } \\
\text { with } \\
\text { others to } \\
\text { generate } \\
\text { value? }\end{array}$ & $\begin{array}{l}\text { How } \\
\text { company } \\
\text { aligns } \\
\text { and } \\
\text { manages } \\
\text { its assets } \\
\text { and } \\
\text { talents? }\end{array}$ & $\begin{array}{l}\text { How } \\
\text { company } \\
\text { employs } \\
\text { signature } \\
\text { and also } \\
\text { superior } \\
\text { technigue } \\
\text { for its work? }\end{array}$ & $\begin{array}{l}\text { How } \\
\text { company } \\
\text { provides } \\
\text { differentiate } \\
d \\
\text { functionaliti } \\
\text { es and } \\
\text { features? }\end{array}$ & $\begin{array}{l}\text { How } \\
\text { company can } \\
\text { generate } \\
\text { complementar } \\
\text { y services and } \\
\text { products? }\end{array}$ & $\begin{array}{l}\text { How } \\
\text { company } \\
\text { can } \\
\text { improve } \\
\text { and } \\
\text { support } \\
\text { values of } \\
\text { its } \\
\text { offerings? }\end{array}$ & $\begin{array}{l}\text { How } \\
\text { company } \\
\text { delivers } \\
\text { the } \\
\text { offering to } \\
\text { users and } \\
\text { customers } \\
\text { ? }\end{array}$ & $\begin{array}{l}\text { How } \\
\text { company } \\
\text { can } \\
\text { represent } \\
\text { its } \\
\text { business } \\
\text { and } \\
\text { offering? }\end{array}$ & $\begin{array}{l}\text { How company } \\
\text { generates } \\
\text { compelling } \\
\text { interactions? }\end{array}$ \\
\hline
\end{tabular}

\subsection{Transformational leadership and innovation}

In a study conducted by Burn (1978), first he introduced transformational leadership theory. Later the scholars, Avolio and Bass(1995) expanded this theory. They noted that transformational leadership is categorized as four main areas including charismatic role modeling, individualized consideration, inspirational motivation and intellectual stimulation.

In 2004, Rafferty and Griffin (cited in Shao et al. (2012), again studied model of theory as presented by Bass and categorized transformational leadership as five subdimensions including vision, inspirational communication, personal recognition, intellectual stimulation and supportive leadership. In addition, confirmatory factor analysis was employed to demonstrate proof of supporting the five sub-dimensions' 
structure of the transformational leadership.

Table 7 below shows these five subdimensions.

Table 7: Five sub-dimensions of Transformational Leadership

\begin{tabular}{|l|l|}
\hline Sub-dimensions & Definitions \\
\hline $\begin{array}{l}\text { Inspirational } \\
\text { Communication }\end{array}$ & $\begin{array}{l}\text { Presenting positive and motivating messages regarding an organization and } \\
\text { confidence and encouraging building statements }\end{array}$ \\
\hline Vision & Visulizing a future idealized image of a firm and its values \\
\hline $\begin{array}{l}\text { Intellectual } \\
\text { Stimulation }\end{array}$ & $\begin{array}{l}\text { To Improve interest of employees to care about problems and also increase } \\
\text { their ability to generate new solving techriques for problems }\end{array}$ \\
\hline Personal Recognition & $\begin{array}{l}\text { To offer revvards for example praise and acknowledgement regarding } \\
\text { initiatives to reach particular }\end{array}$ \\
\hline Supportive Leadership & To show concern for staffs and considering their personal needs \\
\hline
\end{tabular}

Source: Griffin and Rafferty (2004); Shao et al (2012)

Transformational leaders generated innovation level in the organization with the consideration that the organization is innovative. It is important that leaders use inspirational motivation and intellectual stimulation for innovation in organization (Elkins and Keller, 2003; Gumusluoglu and Ilsev, 2009; Shao et al., 2012; Manafi and Subramaniam, 2015).

As noted by Howell and Higgins (1990), the transformational leadership fosters ideas which are creative inside their companies; such act reveals "championing role" of transformational leadership. Such type of leadership suggests a vision which can inspire employees, increases their desire to perform outstanding activities and encourages them to use innovative techniques in their own job functions. The result of such high level motivation then improves organizational innovation (Mumford et al., 2002). Many empirical studies concluded that such leaders have positive impact on level of innovation (Waldman and Awater, 1994). These scholars studied the relationship between innovation and transformational leadership within $R \& D$ departments as well as project management offices. Usually, effects of transformational leadership on innovation in organizations has been a subject of interest between scholars. In a research conducted by Jung et al. (2003), in Taiwan on 32 firms, it was understood that transformational leadership has significant and positive impact on organizational innovation which was calculated according to $R \& D$ expenses and number of received patents during past 3 years.

Besides, transformational leadership has positive impact on innovation success in market. Those leaders who develop innovative vision and demonstrate power and confidence will aim to understand innovation success within a market. Such leaders utilize their employees to improve innovation success (Gumusluoglu and Ilsev, 2009; Manafi and Subramaniam, 2015). Also Keller in (1992) asserted that offering leadership to professional staffs might take more compared 
to leadership method, specifically in $R \& D$ in which quality has the main importance.

In addition to internal roles, transformational leaders might be successful to carry out external roles, for instance through championing/entrepreneurship and also boundary spanning (Howell and Higgins, 1990: Gumusluoglu and Ilsev; 2009). It is necessary for an influential innovative marketing and also for realizing the market behavior.

\section{METHOD AND RESULTS}

This study applied quantitative method to examine the relationship between transformational leadership and innovation. Firstly, 15 hypotheses were developed (See Table 3). Figure1 demonstrates the proposed framework of this study.

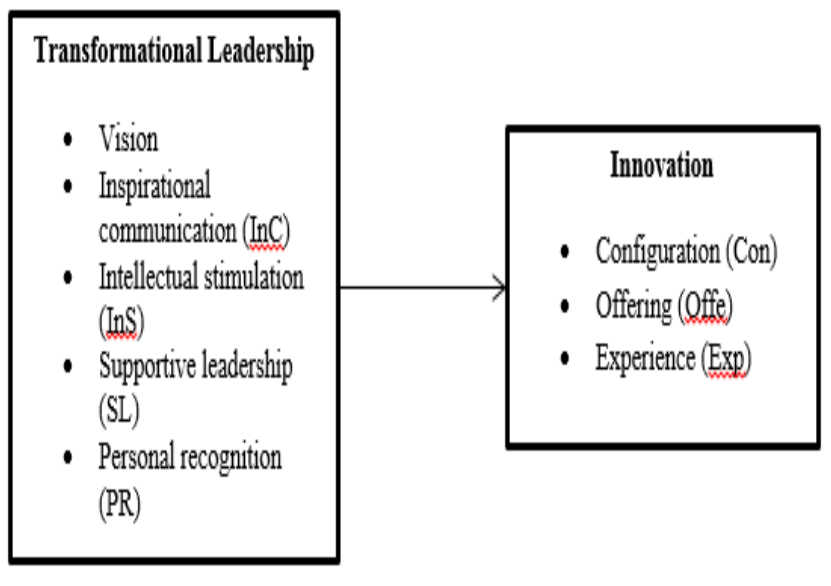

Figure 1: Proposed Framework of the Study

278 data was gathered from 15 government organizations located in four largest cities of Iran. The survey questionnaire was adapted from previous researches which are mentioned in literature review. Based on the research conducted by Manafi and Subramaniam (2015) and Keeley et al. (2013), the questionnaire was designed. The process of data gathering and analysis was done during Jan to May of 2017. The respondents of this study were supervisors, managers, and top managers. They were chosen randomly.

The main statistical method was multiple regression analysis. The main software was SPSS 22. The results of multiple regression analysis can be seen in Table 2 and Table 3.

Table 2: Descriptive Analysis

\begin{tabular}{|l|l|l|}
\hline Variable & Frequency & Percentage \\
\hline Age & & \\
$<20$ & 28 & $10.07 \%$ \\
$21-30$ & 150 & $53.9 \%$ \\
$31-40$ & 60 & $21.5 \%$ \\
41 and above & 40 & $14.3 \%$ \\
\hline Gender & & \\
Male & 133 & $47.8 \%$ \\
Female & 145 & $52.2 \%$ \\
\hline Education & & \\
Diploma & 65 & $23.4 \%$ \\
Bachelor & 177 & $63.6 \%$ \\
Master and above & 36 & $13 \%$ \\
\hline Experience & & \\
Less than 5 & 39 & $14.02 \%$ \\
$6-10$ & 110 & $40.07 \%$ \\
$11-20$ & 66 & $23.74 \%$ \\
21 an above & 63 & $22.66 \%$ \\
\hline
\end{tabular}

According to the results of regression analysis, except 4 hypotheses other hypotheses were accepted by this study (As shown in Table3).

Table 3: Multiple regression analysis's results 


\begin{tabular}{|c|c|c|c|c|c|c|c|}
\hline Impacts & Hypotheses & $\begin{array}{l}\text { B } \\
\text { coefficient }\end{array}$ & $\begin{array}{l}\text { Std. } \\
\text { Error }\end{array}$ & $\mathrm{T}$ & p-value & VIF & Supported \\
\hline $\begin{array}{l}\text { Vision- } \\
\text { Con }\end{array}$ & $\begin{array}{l}\text { H1: Vision has a significant } \\
\text { and positive effect on } \\
\text { configuration }\end{array}$ & .222 & .067 & 3.313 & .002 & 1.11 & Yes \\
\hline InC-Con & $\begin{array}{l}\text { H2:Inspirational } \\
\text { communication has a } \\
\text { significant and positive } \\
\text { effect on configuration }\end{array}$ & .188 & .077 & 2.44 & .041 & 3.409 & Yes \\
\hline InS-Con & $\begin{array}{l}\text { H3: Intellectual stimulation } \\
\text { has a significant and } \\
\text { positive effect } \\
\text { configuration }\end{array}$ & .235 & .052 & 4.519 & .001 & 2.25 & Yes \\
\hline SL-Con & $\begin{array}{l}\text { H4: Supportive leadership } \\
\text { has a significant and } \\
\text { positive effect } \\
\text { configuration }\end{array}$ & .065 & .088 & .738 & .22 & 2.12 & No \\
\hline PR-Con & $\begin{array}{l}\text { H5:Personal recognition has } \\
\text { a significant and positive } \\
\text { effect on configuration }\end{array}$ & .191 & .029 & 6.58 & .003 & 2.78 & Yes \\
\hline \multicolumn{8}{|c|}{$\begin{array}{l}R \text { square: } .85 \\
\text { Constant: } 2.33\end{array}$} \\
\hline $\begin{array}{l}\text { Vision- } \\
\text { Offe }\end{array}$ & $\begin{array}{l}\text { H6: Vision has a significant } \\
\text { and positive effect on } \\
\text { offering }\end{array}$ & .212 & .065 & 3.26 & .004 & 2.01 & Yes \\
\hline InC-Offe & $\begin{array}{l}\text { H7:Inspirational } \\
\text { communication has a } \\
\text { significant and positive } \\
\text { effect on offering }\end{array}$ & .301 & .088 & 3.42 & 0.00 & 1.68 & Yes \\
\hline InS-Offe & $\begin{array}{l}\text { H8: Intellectual stimulation } \\
\text { has a significant and } \\
\text { positive effect on offering }\end{array}$ & .444 & .151 & 2.94 & .002 & 1.68 & Yes \\
\hline SL-Offe & $\begin{array}{l}\text { H9:Supportive leadership } \\
\text { has a significant and } \\
\text { positive effect on offering }\end{array}$ & .066 & .122 & .54 & .78 & 2.13 & No \\
\hline PR-Offe & $\begin{array}{l}\text { H10: Personal recognition } \\
\text { has a significant and } \\
\text { positive effect on offering }\end{array}$ & .188 & .077 & 2.44 & .041 & 3.409 & Yes \\
\hline \multicolumn{8}{|c|}{ Regression Equation: Offe $=4.47+.212($ Vision $)+.301(\operatorname{InC})+.444(\operatorname{InS})+.066(S L)+.188(P R)$} \\
\hline $\begin{array}{l}\text { Vision- } \\
\text { Exp }\end{array}$ & $\begin{array}{l}\text { H11:Vision has a significant } \\
\text { and positive effect on } \\
\text { experience }\end{array}$ & .098 & .43 & .227 & .075 & 2.57 & No \\
\hline InC-Exp & $\begin{array}{l}\text { H12:Inspirational } \\
\text { communication has a } \\
\text { significant and positive } \\
\text { effect on experience }\end{array}$ & .067 & .12 & .54 & .066 & 3.13 & No \\
\hline InS-Exp & $\begin{array}{l}\text { H13:Intellectual stimulation } \\
\text { has a significant and } \\
\text { positive effect on experience }\end{array}$ & .193 & .73 & 2.64 & .022 & 2.22 & Yes \\
\hline SL-Exp & $\begin{array}{l}\text { H14:Supportive leadership } \\
\text { has a significant and } \\
\text { positive effect on experience }\end{array}$ & .226 & .047 & 4.80 & 0.00 & 3.01 & Yes \\
\hline PR-Exp & $\begin{array}{l}\text { H15:Personal recognition } \\
\text { has a significant and } \\
\text { positive effect on experience }\end{array}$ & .311 & .065 & 4.78 & 0.00 & 2.22 & Yes \\
\hline \multicolumn{8}{|c|}{$\begin{array}{l}\text { R square: } .79 \\
\text { Constant: }-1.47 \\
067(\text { Vision })+.193(\operatorname{InC})+.444(\operatorname{InS})+.226(S L)+.311(P R)\end{array}$} \\
\hline
\end{tabular}


As shown in Table 3, except supportive leadership all components of transformational leadership have significant and positive impacts on configuration. The highest impact refers to intellectual stimulation while the lowest impact refers to supportive leadership.

As shown in Table 3, except supportive leadership all components of transformational leadership have significant and positive impacts on offering. The highest impact refers to inspirational communication while the lowest impact refers to supportive leadership.

As shown in Table 3, except vision and inspirational communication all components of transformational leadership have significant and positive impacts on offering. The highest impact refers to intellectual stimulation while the lowest impact refers to vision.

\section{CONCLUSION}

Extant research have shown that transformational leadership can affect organizational performance and particularly innovation. Keeley et al. (2013) have classified different type of innovation in to three categories including, configuration, offering, and experience. This study examined the relationship between transformational leadership's components and innovation's components based on the Keeley's classification. The furfure research can test the proposed framework of this study for other industries and scopes.

\section{REFERENCES}

Avolio, B. J., \& Bass, B. M. (1995). Individual consideration viewed at multiple levels of analysis: A multi-level framework for examining the diffusion of transformational leadership. The leadership quarterly, 6(2), 199-218.

Barney, J. (1991). Firm resources and sustained competitive advantage. Journal of management, 17(1), 99-120.

Burns, J.M. (1978). Leadership. New York: Harper \& Row

Damanpour, F. (1991). Organizational innovation: A meta-analysis of effects of determinants and moderators. Academy of management journal,34(3), 555-590.

Edquist, C., Hommen, L., \& McKelvey, M. D. (2001). Innovation and employment: Process versus product innovation. Edward Elgar Publishing.

Elkins, T., \& Keller, R. T. (2003). Leadership in research and development organizations: A literature review and conceptual framework. The Leadership Quarterly, 14(4), 587-606.

Gumusluoglu, L., \& Ilsev, A. (2009). Transformational leadership, creativity, and organizational innovation. Journal of business research, 62(4), 461473.

Howell, J. M., \& Higgins, C. A. (1990). Champions of technological innovation. Administrative science quarterly, 317-341.

Jung, D. I., Chow, C., \& Wu, A. (2003). The role of transformational leadership in enhancing organizational innovation: Hypotheses and some preliminary findings. The Leadership Quarterly, 14(4), 525-544.

Keller, R. T. (1992). Transformational leadership and the performance of research and development project groups. Journal of management, 18(3), 489-501.

Manafi, M., \& Subramaniam, I. D. (2015). Relationship between human resources management practices, transformational leadership, and knowledge sharing on innovation in iranian electronic industry. Asian Social Science, 11(10), 358.

Mumford, M. D., \& Licuanan, B. (2004). Leading for innovation: Conclusions, issues, and directions. The leadership quarterly, 15(1), 163-171. 
Rafferty, A. E., \& Griffin, M. A. (2004). Dimensions of transformational leadership: Conceptual and empirical extensions. The leadership quarterly, 15(3), 329-354.

Schumpeter, J. (1934). Capitalism, socialism, and democracy.

Shao, Z., Feng, Y., \& Liu, L. (2012). The mediating effect of organizational culture and knowledge sharing on transformational leadership and Enterprise Resource Planning systems success: An empirical study in China. Computers in Human Behavior, 28(6), 24002413.

Waldman, D. A., \& Atwater, L. E. (1994). The nature of effective leadership and championing processes at different levels in a R\&D hierarchy. The Journal of High Technology Management Research,5(2), 233245.

Zohoori, M., Mohseni, S., Samadi, B., \& Attarnezhad, O. (2013). The relationship between knowledge sharing and innovation in electronic industry of Iran. Journal of
Small Business and Entrepreneurship Development, 1(1), 26-33. 